\title{
CONSTITUTIONAL AND EXTRA-CONSTITUTIONAL RESTRAINTS *
}

\section{InConsistent Positions TAken}

In deciding cases which arose under the due process clauses the Supreme Court has at different times taken two positions concerning the powers of government which are unquestionably inconsistent with each other. According to one position the state legislatures over subject-matters not withdrawn from their control, and Congress over subject-matter's entrusted to it, have all governmental powers which are not entrusted by the constitutions to other organs of government and which are not withdrawn from the control of those legislative bodies by other provisions of the ronstitutions. This position is supported by the vast weight of direct authority. A number of the authorities were noted in a former article, ${ }^{1}$ and we shall soon note further authorities in its support.

According to the other position, there are restraints which, although not contained in the constitutions, apply to all organs of government; there are rights which, although not supported by the constitutions, no organ of government may violate; and those restraints, or those rights, are to be ascertained by judicial action. That position is expressed in several ways, so that it will be necessary for us to observe the decisions and dicta under several heads, but there is the common thought which underlies those several lines of cases that there are fundamental rights, inalienable rights, which have an existence independent of any provision of the constitutions but which the courts may recognize and may compel all organs of government to observe. That thought furnishes the real basis of some of the decisions in cases which arise under the due process provision.

As we have already said, those two positions are unquestionably inconsistent with each other. And yet the court has given

* Copyright, 1913, by Robert P. Reeder.

1 U. of Pa. L. Rev., Nov., 1908, pp. 64, 65. 
such inadequate attention to their inconsistency that each position has been expressed by the Supreme Court frequently, and in several cases, of which Twining v. New Jersey may be cited as an instance, the two positions are even stated side by side in the same opinion."

2 (1908) 211 U. S. 78, 29 Sup. Ct. 14

- See the quatation from the opinion in Twining v. New Jersey on p. 448, infra. With it compare the following quotation from the same opinion: "We prefer to rest our decision on broader grounds, and inquire whether the exemption from self-incrimination is of such nature that it must be included in the conception of due process. Is it a fundamental principle of liberty and justice which inheres in the very idea of free government and is the inalienable right of a citizen of such a government? If it is, and is of a nature that pertains to process of law, this court has declared it to be essential to due process of law:" 211 U. S. at 106, 29 Sup. Ct. at 22. "Even if the historical meaning of due process of law and the decisions of this court did not exclude the privilege from it, it would be going far to rate it as an immutable principle of justice which is the inalienable possession of every citizen of a free government. . . . It is at best defended not as an unchangeable principle of universal justice, but as a law proved by experience to be expedient:" 2 II U. S. at 113,29 Sup. Ct. at 25. "Consistently with the requirements of due process, no change in ancient procedure can be made which disregards those fundamental principles, to be ascertained from time to time by judicial action, which have relation to process of law and protect the citizen in his private right, and guard him against the arbitrary action of government. This idea has been many times expressed in differing words by this court, and it seems well to cite some expressions of it. The words duc process of law 'were intended to secure the individual from the arbitrary exercise of the powers of government, unrestrained by the established principles of private rights and distributive justice.' Bank of Columbia v. Okely, (1819) 4 Wheat. 235, 244 (approved in Hurtado v. California (1884), 110 U. S. 516, 527, 4 Sup. Ct. 111, 292, 117 ; Leeper v. Texas, (1891) 139 U. S. 462, 468, 11 Sup. Ct. 577, 579; Scott v. McNeal, (1894) 154 U. S. 34, 45, 14 Sup. Ct. 1108, 1112). 'This. court has never attempted to define with precision the words "due process of law." - . - It is sufficient to say that there are are certain immutable principles of justice which inhere in the very idea of free government which no member of the Union may disregand.' Holden v. Hardy, (1898) I69 U. S. 366, 389, I8 Sup. Ct. 383,387 . 'The same words refer to that law of the land in each state, which derives its authority from the inherent and reserved powers of the state, exerted within the limits of those fundamental principles of liberty and justice which lie at the base of all our civil and political institutions.' In reKemmler, ' (1890) 136 U. S. 436,448 , 10 Sup. Ct. 930,934 . 'The limit of the full controi which the state has in the proceedings of its courts, both in civil and criminal cases, is subject only to the qualification that such procedure must not work a denial of fundamental rights or conflict with specific and applicable provisions of the Federal Constitution.' West v. Louisiana, (1904) I94 U. S. 258, 263, 24 Sup. 650, 652." See 211 U. S. at IOI, 102, 29 Sup. Ct. at 20, 21. 


\section{Power to Declare Governmental Action Unconstitutional}

The position that there are extra-constitutional restraints derives, of course, no support from those cases which sustain the power of the courts to declare the invalidity of governmental action which is clearly unconstitutional.

It is true that the Federal Constitution expressly forbids the courts to enforce provisions of the state laws and the state constitutions which conflict with the Federal Constitution, and that while there is no provision of that Constitution which necessarily requires the courts to decide for themselves whether federal legislative or executive action is compatible with the Constitution, and while for some time there was room for doubt whether in the absence of an express provision to that effect in a constitution a court might refuse to enforce legislation which it considered clearly in conflict with the constitution," nevertheless, since the decision

- Article VI, clause 2, which requires judges to ignore every provision of a state constitution or law which is in conflict with the supreme law of the land, necessarily requires them to decide the question of compatibility before enforcing the state constitution or law. But it does not seem that this clause either by itself or in connection with any other clause necessarily requires the courts to pass an independent judgment upon the compatibility of federal action to the Constitution. See Thayer, John Marshall, 61, 64, 65, 98; book review by Prof. Thayer in 7 Harv. L. Rev. 380; Thayer, Origin and Scope of the American Doctrine of Constitutional Law, 7 Harv. L. Rev. 137, note, reprinted in Thayer, I.egal Essays, 12, note. Compare Watson on the Constitution, 1168, 1180-1183, I192; Coxe, Judicial Power and Unconstitutional Legislation, viii, 67, 272 el seq.; Meigs, Some Recent Attacks on the American Doctrine of Judicial Power, 40 Am. L. Rev. 660 et seq.; Hastings, Is It Usurpation to Hold Void as Unconstitutional Laws, 20 Green Bag, 453. Qucere, does "in pursuance thereof" mean merely "as a consequence of the formation of the new government" and thus assist in creating one obvious difference between laws and treaties or does it also create an additional difference between laws and treaties? See also preceding clause of Article VI; but compare Coxe, $u b i$ supra, 316 , as to the development of this clause in the Convention; and see Meigs, $u b i$ suprc, 662. On the bearing of other provisions of the Constitution see Corwin, The Establishment of Judicial Review, 9 Mich. L. Rev. 102, I19; Corwin, The Supreme Court and Unconstitutional Acts of Congress, 4 Mich. L. Rev. 616; Trickett, The Great Usurpation, 40 Am. L. Rev. 356; Pennoyer, The Income Tax Decision, 29 Am. L. Rev. $555,859,860$.

On the lack of unanimity on this subject about the time of the adoption of the Federal Constitution see Corwin, The Supreme Court and Unconstitutional Acts of Congress, 4 Mich. L. Rev. 616 et seq.; Corwin, The Establishment of Judicial Review, 9 Mich. L. Rev. 102; Thayer, John Marshall, 63, 66, 72; Thayer, The Origin and Scope of the American Doctrine of Constitutional Law, 
in the case of Marbury v. Madison' it has been settled law that the court may pass an independent judgment upon the constitutionality of legislation and refuse to enforce legislation which it considers clearly unconstitutional:? the courts do not regard as strictly binding upon them the interpretation which Congress must necessarily place upon grants of and restrictions upon legislative power before it legislates, as do the courts of continental Europe.*

7 Harv. L. Rev. 129, 132-134, 137, reprinted in Thayer, Legal Essays, 1, 5-7, 11; Willoughby on the Constitution, 5, 6; Beard. The Supreme Court and the Constitution, Chap. 2, p. II3, note; Meigs, The Relation of the Judiciary to the Constitution, 19 Am. L. Rev. 175,178 el seq.; Trickett, The Great Usurpation. 40 Am. L. Rev. 360, 366; Trickett, Judicial Dispensation from Congressional Statutes, 4 Am. L. Rev. 65i Coxe, Judicial Power and Unconstitutional Legislation, chaps. 20-28; Meigs, Some Recent Attacks on the American Doctrine of Judicial Power, 40 Am. L. Rev. 650; Cooley, Constitutional Limitations, 7th ed., 229, note; Federalist, No. 78; Pennoyer, The Income Tax Decision, 29 Am. L. Rev. 860; An Early Constitutional Case in Massachusetts, 7 Harv. L. Rey. 415; Elliott, The Legislatures and the Courts, 5 Pol. Sci. Quar. 23t ef seq.; .McClain, Written and Unwritten Constitutions in the United States, 6 Col. L. Rev. 69, 70; Clark, The Supremacy of the Judiciary, 17 Harv. L. Rev. 1; and see Pierce, Federal Usurpation, 200, 201. On the popular attitude toward the courts also Thayer, The Origin and Scope of the American Doctrine of Constitutional Law, 7 Harv. L. Rev. 132, note; 137. note, reprinted in Thayer, Legal Essays, 5. 11; Bryce, American Commonwealth, 3d ed., I, 501, 451-453; U. S. Constitution, Amendments V-VIII; and see Thayer, John Marshall, 65, 66, 104, 105: Bill of Rights (1688).

- (1803) I Cranch, 137.

The court in that case asserts a general right to refuse to enforce such legislation, although the decision might have been based on a narrower ground. "As this was a question of the constitutional grant of its own powers, it might have assumed the right to ignore any attempted lessening or augmentating of them, without claiming the larger right to interfere with the validity of acts of Congre: which did not pertain to its own jurisdiction:" Trickett, The Great Usurpation, 40 Am. L. Rev. 369. See also Ibid. 375; Coxe, Judicial Power and Unconstitutional Legislation, 10, 20, 337: Thayer, John Marshall, 72 et seg.; Bordwell, The Function of the Judiciary, 7 Col. L. Rev. at 337; Corwin, The Establishment of Judicial Review, 9 Mich. L. Rev, 102, 292; Beard, The Supreme Court and the Constitution, 31, 33, 115, note.

- On the extent to which judges at times regand previous decisions of the court upon constitutional questions as binding upon them see concurring opinion in Dorr v. United States, (1904) r95 U. S. 138, 153, 24 Sup. Ct. 808, 814; Twining v. New Jersey, (1908) 21 I U. S. 78, 98, 99, 29 Sup. Ct. 14, 19; with which consider Lincoln, Inaugural Address (1861); Legal Tender Cases, (1870) 12 Wall. 457; concurring opinions in Butchers' U. Co. v. Crescent C. Co., (1884) III U. S. 746, 4 Sup. Ct. 652; dissenting opinion in Abbott v. Beddingfield, (1899) 125 N. C. 256, 280, 34 S. E. 412, 419; Collins, The Fourteenth Amendment and 


\section{Generaz DUty to EnForce Legislation}

But the cases in which the court declares that it may pass upon the constitutionality of the acts of other departments of government themselves recognize the duty of the courts to enforce legislation unless that legislation is, in the opinion of the courts, unquestionably opposed to any view which may properly be taken of the Constitution." The courts have no general veto power

the States, chap. 8; Shroder, The Doctrine of Stare Decisis-Its Application to Decisions Involving Constitutional Interpretation, 58 Cent. L. J. 29; Machen, The Elasticity of the Constitution, 14 Harv. L. Rev. 202, 206, 207, 209; Chamberlain. The Doctrine of Stare Decisis as Applied to Decisions of Constitutional Questions, 3 Harv. L. Rev. 125; Willoughby on the Constitution, sec. 28; Willoughby, The Supreme Court of the United States, 76, 77; and also Coudert, Certainty and Justice, 14 Yale L. J. 364; Whitney, The Doctrine of Stare Decisis, 3 Mich. L. Rev. 89, 94 et seq.. Ex parte Harding, (19II) 219 U. S. 363, 378, 3I Sup. Ct. 324, 329; Hertz v. Woodman, (Ig10) 218 U. S. 205, 212, 213, 30 Sup. Ct. 621, 622, 623; Chicago, B. \& Q. Ry. Co. v. United States, (1911) 220 U. S. 559, 577, 31 Sup. Ct. 612, 616; Ex parte Holman, (1908) 79 S. C. 9, 13,60 S. E. 19, 21; People v. Tompkins, (1906) 186 N. Y. 413, 79 N. E. 326; Vail v. Arizona, (1907) 207 U. S. 201, 205, 28 Sup. Ct. 107, 108; dissenting opinion in Eakin v. Raub, (1825) 12 S. \& R. (Pa.) 330, 346; dissenting opinion in Standard Oil Co. v. United States, (IgII) 221 U. S. I, 31 Sup. Ct. 502.-As to the formation of independent opinions on constitutional questions see also Marbury v. Madison, (1803) I Cranch, r37; Thayer, John Marshall, 67, 98, 108; Thayer, The Origin and Scope of the American Doctrine of Constitutional Law, 7 Harv. L. Rev. 129. reprinted with additional notes in Thayer, Legal Essays; Corwin, The Supreme Court and Unconstitutional Acts of Congress, 4 Mich. L. Rev. 629, 630; Trickett, The Great Usurpation, 40 Am. L. Rev. 374; Pennoyer, The Income Tax Decision, 29 Am. L. Rev. 557; Meigs, The Relation of the Judiciary to the Constitution, $19 \mathrm{Am}$. L. Rev. 194-199; dissenting opinion in Abbott v. Beddingfield, (1899) 125 N. C. $256,268,272,294,34$ S. E. 412, 415, 416, 424: dissenting opinion in Eakin v. Raub, (1825) $12 \mathrm{~S}$. \& R. (Pa.) 330, 348, 351, 353, 356; Cooley, Constitutional Limitations, 7 th ed., 228; Bryce, American Commonwealth, 3d ed., I, 244; 246, 268, 269; Pjerce, Federal Usurpation, 200. The argument in Clark, The Supremacy of the Judiciary, 17 Harv. L. Rev. 17, 18, is entirely unconvincing.

- See Corwin, The Supreme Court and Unconstitutional Acts of Congress, 4 Mich. L. Rev. 624; Trickett, Judicial Dispensation from Congressional Statutes, 41 Am. L. Rev. at 86, 87; dissenting opinion in Eakin v. Raub, (1825) I2 S. \& R. (Pa.) 330, 349. Compare Thayer, The Origin and Scope of the American Doctrine of Constitutional Law, 7 Harv. L. Rev. 129, reprinted with additional notes in Thayer, Legal Essays; Laurel H. C. v. San Francisco, (1910) 216 U. S. $358,365,31$ Sup. Ct. $301,302$.

${ }^{10}$ See Thayer, The Origin and Scope of the American Doctrine of Constitutional Law, 7 Harv. L. Rev. 138 el seg., reprinted in Thayer, Legal Essay,; Thayer, John Marshall, 106, 108, 110; Bordwell, The Function of the Judiciary, 7 Col. 
over legislation." The Convention of 1787 'repeatedly and emphatically refused to place in the Constitution such a grant of power to the courts, ${ }^{18}$ and it is inconceivable that those who adopted the Constitution granted a similar power by implication.

Passing Upon the Wisdom or Justice of Governiental Action

The question of the propriety of legislation is not judicial in its nature. That question has been entrusted to other departments of government. The Supreme Court has declared repeatedly that it has no right to inquire into the wisdom or justice of acts by other organs of the federal government or by the states or their organs of government; ${ }^{33}$ and some of those statements have been made in

L. Rev. 337; Knoxville v. Knoxville W. Co., (1909) 212 U. S. I, 8, 16, 29 Sup. Ct. 148, 150, 153; Henderson B. Co. v. Henderson City, (1899) 173 U. S. 592, 615, 19 Sup. Ct. 553, 562. On the extent to which this principle is observed by the courts see 19 Pol. Sci. Quar. 589; 21 Harv. L. Rev. 495, 499; Collins, The Fourteenth Amendment and the States, 168-170.

11 The opinion in Marbury v. Madison, (1803) I Cranch, 137, so assumes. See also Muskrat v. United Stàtes, (I91 I) 219 U. S. 346, 357, 31 Sup. Ct. 250, 254; Elliot's Debates, V, 151, 344, 347; Thayer, The Origin and Scope of the American Doctrine of Constitutional Law, 7 Harv. L. Rev. 129, 136 et seq., reprinted in Thayer, Legal Essays, I, II ef seq.; Thayer, John Marshall, chap. 5i discussion in Dorman v. State, (1859) 34 Ala. 216, 232 et seq.; MeMurtrie, The Jursidiction to Declare Void Acts of Legislation, 32 Am. L. Rev. N. S. I094, 1095, 1103: MicMurtrie, A Last Word on Constitutional Construction, $33 \mathrm{Am}$. L. Reg. N. S. 506.

13 See note II, supra.

"Sce the especially strong language used in McCray v. United States, (1904) 195 U. S. 27, 54-61, 24 Sup. Ct. 769, 776-778, in the many opinions there quoted, and in Atkin v. Kansas, (1903) 191 U. S. 207, 223, 24 Sup. Ct. 124, 128; and also Noble State Bank v. Haskell, (I9II) 219 U. S. 575, 580, 31 Sup. Ct. 299, 300; Oceanic N. Co. v. Stranahan, (1909) 214 U. S. 320, 340, 29 Sup. Ct. 671; 676; United States v. Delaware \& H. Co., (1909) 213 U. S. 366, 405, 29 Sup. Ct. 527. 535: Twining v. New Jersey, (1908) 211 U. S. 78, 106, 29 Sup Ct. 14, 22; Hunter v. Pittsburgh, (1907) 207 U. S. 16r, 176, 28 Sup. Ct. 40, 45; Lottery Case-Champion v. Ames, (1903) 188 U. S. 321, 363, 23 Sup. Ct. 321, 329, 330; Louisville \& N. R. Co. v. Kentucky. (1902) 183 U. S. 503, 512, 22 Sup. Ct. 95, 99; New Y. \& N. E. R. Co. v. Bristol, (1894) 151 U. S. 556, 570, 14 Sup. Ct. 437. 441; Powell v. Pennsylvania, (1888) 127 U. S. 678, 686, 8 Sup. Ct. 992, 1257, 996; Purity E. \& T. Co. v. Lynch, (1912) 226 U. S. 192, 201, 33 Sup. Ct. 44, 46; Red "C" O: M. Co. v. North Carolina, (1912) 222 U. S. 380, 394, 395, 32 Sup. Ct. I52, 156; Flint v. Stone Tracy Co., (1911) 220 U. S. 107, 153, 154, 31 Sup. Ct. 342, 350; Brodnax v. Missouri, (1911) 219 U. S. 285, 293, 31 Sup. Ct. 238, 240; Shevlin-Carpenter Co. v. Minnesota, (rg10) 218 U. S. 57, 70, 30 Sup. Ct. 663, 667; District of Columbia v. Brooke, (1909) 214 U. S. 138, 150, 29 Sup. Ct. 560, 
language which was decidedly vigorous. And, indeed, even if there were no constitutional objection to the making of such an inquiry by the court, the inconvenience of leaving the validity of

563: Railroad Comn. of Louisiana v. Cumberland T. \& T. Co., (1909) 212 U. S. 414, 420, 29 Sup. Ct. 357, 360; Waters-Pierce Oil Co. v. Deselms, (1909) 212 U. S. 159, 174, 29 Sup. Ct. 270, 274; St. Louis, I. M. \& S. Ry. Co. v. Taylor, (1908) 210 U. S. 281, 295, 28 Sup Ct. 616, 621; Armour P. Co. v. United States, (1908) 209 U. S. 56, 82, 28 Sup. Ct. 428, 435; Sauer v. New York, (1907) 206 U. S. 536, 547,27 Sup. Ct. 686, 689; Hennington v. Georgia, (1896) 163 U. S, 299. 304, 16 Sup. Ct. 1086, 1088; Chicago, B. \& Q. R. Co. v: McGuire, (19r1) 2 I9 U. S. 549 , 569, 31 Sup. Ct. 259, 263; Louisville \& N. R. Co. v. Mottley, (1911) 219 U. S. 467, 474, 31 Sup. Ct. 265, 267; Ling Su Fan v. United States, (1910) 218 U. S. 302, 317 , 3 Sup. Ct. 21, 23; Grenada L. Co. v. Mississippi, (1910) 217 U. S. 433, 44I, 30 Sup. Ct. 535, 539; Southwestern Oil Co. v. Texas, (1910) 217 U. S. II4, 127, 30 Sup. Ct. 496, 501; Interstate Com. Comn. v. Illinois C. R. Co., (19ro) 215 U. S. 452, 470, 30 Sup. Ct. 155, 160; Mclean v. Arkansas, (1909) 21 I U. S. 539. 547, 548, 29 Sup. Ct. 206, 208; Employers' Liability Cases-Howard v. Illinois C. R. Co., (1908) 207 U. S. 463, 492, 28 Sup. Ct. 141, 143; Heath \& M. M. Co. v. Worst, (1907) 207 U. S. 338, 357, 28 Sup. Ct. 114, 120; Whitfield v. Aetna L. I. Co., (1907) 205 U. S. 489, 495, 27 Sup. Ct. 578, 579; Patterson v. Colorado, (1907) 205 U. S. 454, 46r, 27 Sup Ct. 556, 557; St. Mary's F. A. P. Co. v. West Virginia, (1906) 203 U. S. 183, 192, 27 Sup. Ct. 132, 135; Hooker v. Los Angeles, (1903) 188 U. S. 314, 320, 23 Sup. Ct. 395, 397; Patton v. Brady, (1902) 184 U.. S. 608, 623, 22 Sup. Ct. 493, 498; L'Hote v. New Orleans, (1900) 177 U. S. 587, 597, 20 Sup. Ct. 791, 792; Ohio Oil Co. v. Indiana, (1900) 177 U. S. 190, 211 , 20 Sup. Ct. 576, 585; Chicago, M. \& St. P. Ry. Co. v. Tompkins, (1900) 176 U. S. 167, 173, 20 Sup. Ct. 336, 338; Fallbrook Irr. Dist. v. Bradley, (1896) 164 U. S: 112, 157, 17 Sup. Ct. 56,62; County of Mobile v. Kimball, (1880) 102 U. S. 691, 704; Springer v. United States, (1880) 102 U. S. 586, 594; Ex perte Siebold, (1879) 100 U. S. 371, 393; Legal Tender Cases, (1872) 12 Wall. 457. 552; discussion in the case of Dorman v. State, (1859) 34 Ala. 216, 235; West Virginia v. Dent, (1884) 25 W. Va. 1, 21; 22; Sedgwick, Construction of Statutory and Constitutional Law, 2d ed., 154, 183 et seq.; 21 Harv. L. Rev. $495 ; 4$ Harv. L. Rev. 386; 32 Am. L. Reg. N. S. 5, 596; 33 Am. L. Reg. N. S. 512; McMurtrie, Observations on Mr. George Bancroft's Plea for the Constitution, pp. 5, 7, 26; Bryce, The American Commonwealth, $3 d$ ed., I, 253; and see Willoughby, The Nature of the State, 77, 85; Blackstone, Commentaries, 1, "9r. Compare 19 Pol. Sci.'Quar. 589; 21 Harv. L. Rev. 495, 499, Collins, The Fourteenth Amendment and the States, 168-170, on the extent to which the principle is observed by the courts; Interstate Com. Comn. v. Union P. Ry. Co., (1912) 222 U. S. 541, 547, 548, 32 Sup. Ct. 108, 111; Interstate Com. Comn. v. Illinois C. R. Co. and McLean v. Arkansas, supra; Michigan C. R. Co. v. Powers, (1906) 201 U. S. 245. 300, 26 Sup. Ct. 459, 465; United States v. Joint T. Assn., (1898) 17 I U. S. 505, 571, I9 Sup. Ct. 25, 32; and opinion of Chase, J., in Calder v. Bull, (1798) 3 Dall. 386, 388 . Justice Chase, it will be remembered, was a justice who left the court without a quorum while he made political speeches, who even made such a specch to a grand jury, and whose conduct in the Alien and Sedition case has been severely criticized. 
a law in uncertainty for years and of allowing a court upon 80 indefinite a ground" to decide retroactively long after its enactment that the law was void $a b$ initio would constitute a very grave practical objection to such a course."10

\section{The Ninte Amendment}

Moreover, the declaration of the Ninth Amendment that "the enumeration in the Constitution of certain rights shall not be construed to deny or disparage others retained by the people" merely provides against an erroneous inference from other parts of the Constitution. It It does not authorize courts to refuse to enforce legislation upon the ground that Congress has violated rights unnamed in the Constitution. And it has no bearing whatever upon state legislation.

\section{Rule Stated in Twining v. New Jersey}

But it is not necessary for us to go into a further consideration of the authorities in support of this position. The court unquestionably declared correctly when it said in Twining v. New Jersey, "It must not be forgatten that in a free representative government nothing is more fundamental than the right of the people through their appointed servants to govern themselves in accordance with

"See McMurtrie, The Jurisdiction to Declare Void Acts of Legislation, 32 Am. L. Reg. N. S. 1108; with which compare Pollock, The Law of Reason, 2 Mich. L. Rev. 159, 173; Pollock, The Expansion of the Commoni Law, \& Col. L. Rev. 171, 187.

1s See McMurtrie, A Last Word on Constitutional Construction, 33 Am. L. Reg. N. S. 511, 512; McMurtrie, Note on Constitutional Law, 32 Am. L. Reg* N. S. 595; Trickett, The Great Usurpation, 40 Am. L. Rev. 362-365, 376; Norton v. Shelby County, (1886) I18 U. S. 425, 442, 6 Sup. Ct. I121, 1125: Smalley, Railroad Rate Control (Publications of the American Economic Assn.), IIf117; Knoxville v. Knoxville W. Co., (rg09) 212 U. S. 1, 16, 29 Sup. Ct. 148, 153; Collins, The Fourteenth Amendment and the States, 132, 136, 154, 158; Hadley, The Eleventh Amendment, 66 Cent. L. J. 71, 76; Ransom, Majority Rule and the Judiciary, 62; Cooley, Constitutional Limitations, 7th ed., 259; Bryce, American Commonwealth, 3d ed., I, 250, 264; and also Thayer, John Marahall, 102 et seg., 10g. Compare McMurtrie, ubi supra, 33 Am. L. Reg. N. S. 507.

${ }^{20}$ See Annals of Congress, 1, 456; Thorpe, Constitutional History of the United States, II, 218; The Federalist, No. 84; Story on the Constitution, sec. $44^{8 .}$

${ }^{17}$ (1908) 211 U. S. 78, 106, 107, 29 Sup. Ct. 14, 22, 23. Compare expression in that opinion quoted in note 3 , supra. 
their own will, except so far as they have restrained themselves by constitutional limits specifically established, and that in our peculiar dual form of government nothing is more fundamental than the full power of the state to order its own affairs and govern its own people, except so far as the Federal Constitution expressly or by fair implication has withdrawn that power. The power of the people of the states to make and alter their laws at pleasure is the greatest security for liberty and justice, this court has said in Hurtado v. California." We are not invested with the jurisdiction to pass upon the expediency, wisdom or justice of the laws of the states as declared by their courts, but only to determine their conformity with the Federal Constitution and the paramount laws enacted pursuant to it. Under the guise of interpreting the Constitution we must take care that we do not import into the discussion our own personal views of what would be wise, just and fitting rules of government to be adopted by a free people and confound them with constitutional limitations. The question before us is the meaning of a constitutional provision which forbids the states to deny to any person due process of law. In the decision of this question we have authority to take into account only those fundamental rights which are expressed in that provision."

\section{Extra-Constitutional Restraints and Rights}

And yet in a number of other cases, as we have already pointed out," there are expressions in favor of the recognition of extraconstitutional restraints and rights. It is quite probable that there is no case in which that position constitutes the only avowed ground for the decision. ${ }^{20}$ Indeed, the Supreme Court itself has

"1 (1884) 110 U. S. 516, 535, + Sup. Ct. 111, 292, 121.

"See p. 441, supro.

so "It may be remarked here that the doctrine of declaring legislative act: void as being contrary to the constitution, was probably helped into existence by a theory which found some favor among our ancestors at the time of the Revolution, that courts might disregard such acts if they were contrary to the fundamental maxims of morality, or, as it was phrased, to the laws of nature. Such a doctrine was thought to have been asserted by English writers, and even by judges at times, but was never acted on. It has been repeated here, as a matter of speculation, by our earlier judges, and occasionally by later ones; but in no case within my knowledge has it ever been enforced where it was the single and necessary ground of the decision, nor can it be, unless as a revolutionary measure:" Thayer, The Origin and Scope of the American Doctrine of Constitutional Law, 7 Harv. L. Rev. 129, 133, reprinted in Thayer, Legal Essays, 1. 6, 7. See also notes to above passage. 
said recently that rarely if ever has it been unable to find some remedy consistent with the law for acts which violated natural justice.21 Yet the fact remains that in a number of instances the court speaks of restraints and rights which, in view of the history of some of the terms used and the conceptions involved in others of the terms, are clearly considered as existing regardless of constitutional provisions. And while the court upon some of those occasions speaks of restraints and rights which it designates in those terms as supported by the constitutions, it does not by the use of such language show that consistency exists between the basicides. that there are extra-constitutional restraints and rights which may be enforced against all organs of government and the other basic idea that some organs of government have all governmental powers except those which are denied to them by the conștitutions.

\section{INALIENABLE RIGBTS .}

There are a few statements in approval of the theory of inalienable rights in opinions which are not very recent; $;$ and even

u "Suffice it to say, that the court's have rarely, if ever, felt themselves so restrained by technical rules that they could not find some remedy, consistent with the law, for acts, whether done by government or by individual persons, that violated natural justice or were hostile to the fundamental principles devised for the protection of the essential rights of property:" Monongahela B. Co. v. United States, (I910) 216 U. S. 177, 195, 30 Sup. Ct. 356, 361. See also Corwin, The Supreme Court and the Fourteenth Amendment, 7 Mich. L. Rev. 643, where it is said, "Given a sufficient hardihood of purpose at the rack of exegesis, and any document, no matter what its fortitude, will eventually give forth the mcaning required of it;" and the language of Harlan, J., when orally announcing his dissent from the decision in Standard Oil Co. v. United States, (rgr $x$ ) printed . in 68 Legal Intelligencer, p. 318, col. 4. And see 24 Harv. L. Rev. at $470,471$.

$=$ In Cummings v. Missouri, (1866) 4 Wall. 277, which was decided before the adoption of the Fourteenth Amendment, and in which an ex post focto law was declared unconstitutional, the court said, speaking by Justice Field, that the "theory upon which our political institutions rest is, that all men have certain inalienable rights:" 4 Wall. at 321. But in the Slaughter House Cases, (1872) 16 Wall. 36, which were decided after the adoption of the Fourteenth Amendment, while Justice Field reiterated his views concerning the existence of inalienable rights in a dissenting opinion in which three other justices concurred, (16 Wall. at 96, 105, 110, 111 ) those views were rejected by a majority of the court; . and in Butchers' U. Co. v. Crescent C. Co., (1884) 11 I U. S. 746, 4 Sup. Ct. 652, while similar views were expressed, (111 U, S. at 756, 757, 762, 4 Sup. Ct. at 657,660 ) they were expressed only in opinions which concurred in the judgment upon grounds which did not appeal to a majority of the court and the ac- 
in some of the more recent cases there are casual dicta in which it is assumed that there are inalienable rights."

\section{Naturaz Justice, Natural Rights}

There are some mild expressions in several other opinions in favor of judicial recognition of natural justice or natural rights as possessing authority superior to legislation," although in still other opinions such superiority is denied. ${ }^{25}$

ceptance of which would have meant the overruling of the Slaughter House decision. A statement from one of those "concurring" opinions in the Butchera' Union case was, however, referred to with approval in the opinion of the court in Allgeyer v. Loussiana, (1897) 165 U. S. 578, 589, 17 Sup. Ct. 427, 431. And see Corwin, The Doctıine of Due Process of Law Before the Civil War, 24 Harv. L. Kev. 36r, 375; with which compare Satterles v. Matthewson, (1829) a Pet. 380, 413, 414.

"Frisbie v. United States, (1895) I57 U. S. 160, 165, 15 Sup. Ct. 586, 588; Jacobson v. Massachusetts, (I905) I97 U. S. I1, 29, 25 Sup. Ct. 358, 362; Twining v. New Jersey, (1908) 21 I U.S. 78, 106, 110, 113, 29 Sup. Ct. 14, 22, 24, 25. See also 211 U. S. at 101, 102, 29 Sup. Ct. at 20, 21, quoted in note 3, on p. 442, supra. Compare discussion on p. 456, infra.

${ }^{24}$ Dicta in Holden v. Hardy, (1898) 169 U. S. 366, 390, 18 Sup. Ct. 383 . 387; Turpin v. Lemon, (1902) 187 U. S. 51, 57,60, 23 Sup. Ct. 20, 23, 24; Arndt v. Grig:s, (1890) 134 U. S. 316, 321, 10 Sup. Ct. 557, 559, of which the passage last cited may possibly express the thought, on which we shall not now comment. that specific provisions of the Constitution will be enforced literally but that a provision which the court considers less definite will be applied only against governmental actions which the court considers to be against natural justice. See also Monongahela B. Co. v. L'nited States, (1910) 216 U. S. 177, 195, 30 Sup. Ct. 356. 361; Chicago, B. \& Q. R. Co. v. Chicago, (1897) 166 U. S. 226, 236, 17 Sup. Ct. 581, 584; Hurtado v. California, (1884) 110 U. S. 516, 535, 4 Sup. Ct. III, 292, 120; License Tax Cases, (1866) 5 Wall. 462, 469; Terrett v. Taylor, (1815) 9 Cranch, 43, 52; language of Chase, J., in Calder v. Bull, (1798) 3 Dall. 386,388 ; dissenting opinion in Chicago, B. \& Q. Ry. Co. v. People, (1906) 200 U. S. 561, 598, 599, 26 Sup. Ct. 341, 352; dissenting opinion in Slaughter House Cases, (1872)16 Wall. 36, 96; "concurring" opinion in Butchers' U. Co. v. Cresscent C. Co., (1884) iा I U. S. 746, 754, 4 Sup Ct. 652, 659.

${ }^{23}$ New Y. \& N. E. R. Co. v. Bristol, (1894) 15I U. S. 556, 570, 14 Sup. Ct. 437. 441. And see language of Fredell, J., in Calder v. Bull, (3798) 3 Dall. 386 , 398, 399; Elliot's Debates, V. $34+$ el seg.; dissenting opinion in Loan Assn. v. Topeka, (1875) 20 Wall. 655. 668; language of author of opinion in Loan Assn. $v$. Topeka in dissenting opinion in Hepburn v. Griswold, (1869) 8 Wall. 603. 638, (the decision in Hepburn v. Griswold from which he dissented was overruled in the Legal Tender Cases, (1870) 12 Wall. 457, and the decision which he announced in Loan Assn. v. Topeka was somewhat explained by him in Davidson v. Kicw Orleans, (1877) 96 U. S. 97, 105); quotation in note 20, supra; Hedderich v. State, (1885) yor Inci. 564, 566. 1 N. E. 47; Dorman v. State, (1859) 


\section{Fundamental Rights}

In cases which arose after the Spanish war there are suggestions that, while some of the provisions of the Federal Constitution are not in force in territory which is subject to the federal government but which has not been "incorporated" into the United States, yet in such territory even "where there is no direct command of the Constitution which applies, there may nevertheless be restrictions of so fundamental a nature that they cannot be transgressed, although not expressed in so many words in the Constitution.' 're

34 Ala. 216, 232 ef seq.; Black, Constitutional Law, 3d ed., p. 72; Dec. Dig., Const. Lay, sec. 39; Bryce, American Commonwealth, 3d ed., I, 447; Pattereon, The United States and the States Under the Constitution, 2d ed., p. 10; Sutherland, Statutory Construction, ad ed., sec. 85; Cooley, Constitutional Limitations, 7th ed., 233: Sedgwick, Construction of Siatutory and Constitutional Law, 2d ed., I54-159; McMurtrie, The Jurisdiction to Declare Void Acts of Legislation, 32 Am. L. Reg. N. S. 1108 ; McMurtrie, A Last Word on Constitutional Construction, 33 Am. L. Reg. N.S. 512. - On the theory of natural justice ales note 32 , infra.

21 "Whilst, therefore, there is no express or implied limitation on Congress in exercising its power to create local govenments for any and all of the territories, by which that body is restrained from the widest latitu de of discretion. it does not follow that there may not be inherent, though unexpressed, principles which are the basis of all free government which cannot be with impunity trenscended. But this does not suggest that every express limitation of the Constitution which is applicable has not force, but only signifies that even in casea where there is no direct command of the Constitution which applies, there may nevertheless be restrictions of so fundamental a nature that they ca nnot be transgressed, although not expressed in so many frords in the Constitution:" from separate opinion in Downes v. Bidwell, (1901) 182 U. S. 244, 290, 291, 21 Sup. Ct. 770, 788, by White, J., in which Shiras and McKenna, JJ., concurred and with which Gray. J., agreed in substance The above language was quoted with apparent approval by Day, J., in the opinion of the court in Dorr v. United Staten, (1904) 195 U. S. 138, 147, 24 Sup. Ct. 808, 812. The statement of Bradley, J., in the Mormon Church Case-Late Corporation of the Church of Jesus Christ v. United States, (1890) 136 U. S. 1, 44, 10 Sup. Ct. 792, 803, that "Doubtles" Congress, in legislating for the Territories would be subject to those fundamental limitations in favor of personal rights which are formulated in the Constitution and its Amendments; but these limitations would exist rather by inference and the general spirit of the Constitution from which Congress derives all its powern, than by any express and direct application of its provisions," is quoted with approval by Brown, J., in his separate opinion in Downes v. Bidwell, (1901) 182 U. S. 244, 268, 2 I Sup. Ct. 770, 780, and is also quoted in the opinion of the court in Dorr v. United States, (1904) 195 U. S. 138, 146, 24 Sup. Ct. 808, 813. See slso opinion of the court in Dorr v. United States, (1904) 195 U. S. 138, 148, 24 
And in other cases which arose in territory which is unquestionably part of the United States there are expressions of which the precise meaning is doubtful but which may indicate the position that "fundamental rights" are as such inviolable; although

Sup. Ct. 808, 812; separate opinions of Brown, J., in Hawaii v. Mankichi, (1903) I90 U. S. 197, 218,23 Sup. Ct. 787, 791; Downes v. Bidwell, (rgor) 182 U. S. $244,282,21$ Sup. Ct. 770, 785; and opinion of court in Knowlton v. Moore, (1900) 178 U. S. 41, 109, 20 Sup. Ct. 747, 774, quoted in opinion last cited. Consider, however, the vigorous criticisms of the views expressed above in McClain, Written and Unwritten Constitutions in the United States, 6 Col. L. Rev. 69, - 73. 79, 80; Patterson. The United States and the States Under the Constitution, 2d ed., p. 10; Pierce, Federal Usurpation, 228 et seq.; Campbell v. Jackman Bros. (1908) I40 Iowa, 475,118 N. W. 755; Ward L. Co. v. Henderson-White M. Co., (1907) 107 Va. 626,59 S. E. 476.

${ }^{17}$ In United States v. Cruikshank, (1875) 92 U. S. 542, 554, the court wid that the Fourteenth Amendment "simply furnishes an additional guaranty against any encroachment by the states upon the fundamental rights which belong to every citizen as a member of society." But this was a mere dictum. In Knowiton v. Moore, (1900) I78 U. S. 41, 109, 20 Sup. Ct. 747, 774, the court mentioned the contention that it could apply "inherent and fundamental principles for the protection of the individual, cven though there be no express authority in the Constitution to do "so," but said that the facts of the case were not such as to require the court to consider that contention. In Hurtado v. California, (1884) r10 U. S. 516, 534, 535, 4 Sup. Ct. 1IT, 292, 120, the court said that the provision for due process of law in the Fifth Amendment "refers to that law of the land which derives its authority from the legislative powers conferred upon Congress by the Constitution of the United States, exercised within the limits therein prescribed, and interpreted according to the principles of the common law. In the Fourteenth Amendment, by parity of reasoning, it refers to that law of the land in each state, which derives its authority from the inherent and reserved powers of the state, exerted within the limits of those fundamental principles of liberty and justice which lie at the base of all our civil and political institutions, and the greatest security for which resides in the right of the people to make their own laws, and alter them at their pleasure." A large part of this statement is repeated in In re Kemmler, (1890) 136 U. S. 436, 448, to Sup. Ct. 930, 934, and part of it which relates to the Fourteenth Amendment is repeated in Twining v. New Jersey, (1908) 211 U. S. 78, 102, 29 Sup. Ct. 14, 21, in such 2 connection that it is quite possible that it is given a meaning diferent from that which was orizinally intended. In other portions of the opinion in the Hurtado case the court assumed, as it has often done, that the provision for due process of law, standing alone, has the same meaning in both the Fifth Amendment and the Fourteenth Amendment, and in the passage quoted the court uses the expression "by parity of reason." It is, therefore, quite probable that the court referred to "the fundamental principles of liberty and justice" merely for rhetorical effect and that it did not seriously intend to declare that the provision in the Fourteenth Amendment possesses a ecope frider than that which the court in the passage quoted doclares to be the scope of the provision in the Fifth Amendment. In 
from the language used in still other opinions it seems quite possible that usually if not always when the court says that the Fourteenth Amendment protects fundamental rights it means merely that in interpreting provisions which are couched in general language it may regard the maxim "de minimis non curat lex."

Howard v. Kentucky, (1906) 200 U. S. 164, 173, 26 Sup. Ct. 189, 191, the court said, "It may be admitted that the prords 'due process of law,' as used in the Fourteenth Amendment, protect fundamental rights." See also American L. Co. v. Zeiss, (1911) 219 U. S. 47, 66, 31 Sup. Ct. 200, 207; Carroll v. Greenwich I. Co., (1905) 199 U. S. 401, 410, 26 Sup. Ct. 66, 67; Backus v. Fort S. U. D. Co., (1898) 169 U. S. 557, 576, 18 Sup. Ct. 445, 452; Twining v. New Jersey, (1908) 211 U. S. 78, 101, 102, 106, 110, 29 Sup. Ct. 14, 20, 22, 24 (with which compare 211 U, S. at 107, 29 Sup. Ct. at 23); the concession simply for argument in McCray v. United States, (1904) 195 U. S. 27. 63, 64, 24 Sup. Ct. 769, 779, 780; "concurring" opinion in Butchers' U. Co. v. Crescent C. Co., (1884) 111 U. S. 746, 759, 4 Sup Ct. 652, 661, 662; dissenting opinions in Slaughter House Cases, (1872) 16 Wall. $36,87,95,106,114,116$.

2 In Watson v. Maryland, (1910) 218 U. S. 173, 177, 30 Sup. Ct. 644, 646, the court said, "The federal courts can only interfere when fundamental rights guaranteed by the Federal Constitution are violated in the enactment of such statutes." In Ballard v. Hunter, (1907) 204 U. S. 241, 262, 27 Sup. Ct. 261, 269 , it said, "The laws of a state come under the prohibition of the Fourteenth Amendment only when they infringe fundamental rights. A law must be framed and judged of in consideration of the practical affairs of man." In Rogers v. Peck, (1905) 199 U. S. 425, 434, 26 Sup. Ct. 87, 89, the court said, "It is only where fundamental rights, specially secured by the Federal Constitution, are invaded, that such interference is parranted," and this position was cited in Franklin v. South Carolina, (1910) 218 U. S. 161, 165, 30 Sup. Ct. 640, 641. In Brown v. New Jersey, (1899) 175 U. S. 172, 175, 20 Sup. Ct. 77, 78, the court said that the state has full control over the procedure in its courts both in civil and criminal cases, "subject only to the qualification that such procedure must not work a denial of fundamental rights or conflict with specific and applicable provisions of the Federal Constitution," and this statement was repeated with approval in West v. Louisiana, (1904) 194 U. S. 258, 263, 24 Sup. Ct. 650, 652; Waters-Pience Oil Co. v. Texas, (1909) 212 U. S. 86, 107, 29 Sup. Ct. 220, 225 . If the language just quoted may be interpreted as suggested in the text, no objection can be made to the position of the court, but the expressions in those opinions are quite objectionable if they are on a par with the suggestions contained in the dicta in Lawton v. Steele, (1894) 152 U. S. 133, 140, 14 Sup. Ct. 499,502 , that "An act of the legislature which has for its object the preservation of the public interests against the illegal depredations of private individuals ought to be sustained, unless it is plainly violative of the Constitution or subversive of private rights," and in Halter v. Nebraska, (1907) 205. U. S. 34, 45, 27 Sup. Ct. 419, 423, that "It would be going very far to say that the statute in question had no reasonable connection with the common good and was not promotive of the peace, order and well-being of the people. Before this court can hold the statute void it must say that and, in addition, adjudge that it violates 


\section{"Essential Nature of All Free Governments."}

The court has also said that upon all organs of government there are limitations "which grow out of the essential nature of all free governments."

rights secured by the Constitution of the United States. We cannot so say and cannot so adjudge;" and with the language of Field, J., dissenting, in Slaughter House Cases, (1872) 16 Wall. 36, 87.- On the subject of this note in general see also other statements in West v. Louisiana, (1904) 194 U. S. 258, 263, 24 Sup. Ct. 650, 652; and also Allen v. Georgia, (1897) 166 U. S. 138, 140, 141, 17 Sup. Ct. 525. 526; Wilson v. North Carolina, (1898) 169 U. S. 586, 594, 18 Sup. Ct. 435 , 438.

" Madisonville T. Co. v. St. Bernard M. Co., (1905) I96 U. S. 239, 251, 252, 25 Sup. Ct. 25r, 256; Loan Assn. v. Topeke, (1874) 20 Wall. 655, 662, 663 (where the declaration was made in spite of an able and unanswerable dissenting opinion from Clifford, J.; see also the language of the author of the opinion in Loan Assn. v. Topeka in dissenting opinion in Hepbum v. Griswold, (1869) 8 Wall. 603, 638; the decision in Hepburn v. Griswold from which he dissented was overruled in the Legal Tender Cases, (1870) 12 Wall. 457, and the decision which he announced in Loan Assn. v. Topeka was somewhat explained by him in Davidson v. New Orleans, (1877) 96 U. S. 97, 105). See also Terrett v. Taylor, (1815) 9 Cranch, 43, 50, 51, 52, a case which, it will be noted, came from a lower federal court and not from a statt court, but where the opinion should have referred simply to the impairment of contract clause; diccum in Holden v. Hardy, (1898) 169 U. S. 366,389 , 18 Sup. Ct. 383,387 ; the concession simply for argument in McCray v. United States, (1904) 195 U. S. 27, 63, 24 Sup. Ct. 769, 779; suggestion in Giozza v. Tiernan, (1893) 148 U. S. 657, 66r, 13 Sup. Ct. 721, 723 (with which suggestion compare language of author of that opinion in McPherson v. Blacker, (1892) I46 U. S. 1, 25, 13 Sup. Ct. 3, 7; New Y. \& N. E. R. Co. v. Bristol, (1894) I5I U. S. 556. 570, 14 Sup. Ct. 437, 441); dictum in Hurtado v. California, (1893) 110 U. S. 516, 535, 4 Sup. Ct. $111,292,120$, (discussed in note 27, supra); dictum in Wilkinson v. Leland, (1829) 2 Pet. 627, 656-658; separate opinion of Chase, J., in Calder v. Bull, (1798) 3 Dall. 386, 388; suggestion in Fletcher v. Peck, (1810) 6 Cranch, 87, 135, 136. The suggestion last cited is explained in Satterlee v. Matthewson, (1829) 2 Pet. 380, 413, 414, where, aiter saying that a state law which divested rights which had been vested by law, but which did not impair the obligation of any contract, would not violate the Constitution of the United States, the court pointed out that the suggestion in Fletcher v. Peck must bo considered simply as relating to the state constitution, which the court might interpret in a case which like Fletcher v. Peck, came to it from a federal court and not from a state court. - With the citations in this note compare language of Iredell, J., in Calder v. Bull, (1798) 3 Dall. 386, 398; Dorman v. State, (1859) 34 Ala. 216, 232 et seq.; Black, Constitutional Law, 3d. ed., p. 72, 2d ed., pp. 63, 64; Patterson, The United States and the States Under the Constitution, 2d ed., p. Io; Cooley, Constitutional Limitations, 7th ed.. 237-239; McClain, Unwritten Constitutions in the United States, 15 Harv. L. Rev. 531; Story on the Constitution, 5th ed., II, 568, note; Dale, Implied Limitations Upon Legislative Power, 24 Am. Bar Assn. Proc. 294, 315-319.-There is 


\section{Discussion on Inalienable Rigats, etc.}

The statements concerning inalienable rights to which we have referred follow the language of a broad assertion of general principle which is made at the outset of the Declaration of Independence. But the assertion of such a general principle in the Declaration of Independence does not show that the courts may declare that legislation is void because it violates what the courts may determine to be inalienable rights, for the Declaration is not part of the Constitution of the United States, 10 and even if it were part of that Constitution it would be going far to say that the general statement of the Declaration of Independence that men possess inalienable rights should be given a weight which the court refuses to give to the general statements in the-Preamble to that Constitution which was framed in 1787. The statements concerning inalienable rights are, therefore, in the same category as those concerning, natural justice, those concerning the possession of fundamental rights which are not expressed in the constitutions and those concerning rights which are said to grow out of the essential nature of all free governments.

As to all such statements it is sufficient to say that the premises upon which they are based have been abandoned by thought-

a dictum in Jacobson v. Massachusetts, (I905) 197 U.S. II, 29, 25 Sup. Ct. 358, 362 , that "there is, of course, a sphere within which the individual may assert the supremacy of his own will, and rightfully dispute the authority of any humaa government, especially of any free government existing under a written constitution, to interfere with the exercise of that will." But, of course, it cannot be successfully contended that in all frez governments in which there are written constitutions the courts may interfere to enforce the provisions of those constitutions. And even in the United States, where the courts do enforce, with some exceptions, the provisions of the written constitutions, the mere fact that 2 cosstitution is written is immaterial apart from the contents of that consitution, unless, indeed, we may say that "given \& sufficient hardihood of purpose at the rack of eregesis, and any document, no matter what its fortitude, will eventwally give forth the meaning required of it:" 7 Mich. L. Rev. 643.

"Yet the language of Bradley, J., dissenting, in Slaughter House Casts. (1872) 16 Wall. 36, r20; concurring in Butchers' U. Co. v. Crescent C. Co.. (1884) III U. S. 746, 762, \& Sup. Ct. 652, 657, suggests that it was his opinion that our modern legislative bodies are restrained even by some of the old English statutea. Compare Beard, The Supreme Court and the Constitution, chap. \&. as ahowing the relation of the Constitution to the Declaration of Independence.

n Jacobsos r. Massachusetts, (1905) 197 U. S. 11, 22, 25 Sup. Ct 358, 359. 
ful men for over a century, that those statements are against the vast weight of direct authority; and that the court has not attempted to support them by any discussion of principle.

Robert P. Reeder.

Philadelphia, March ror3.

$m$ On the theory of natural justice see note ${ }^{25}$, supra, and Lee v. Bude \& $T$. J. Ry. Co., (1871) L. R. 6 C. P. 576, 582; Dicey, The Law of the Constitution 7th ed., 59; Holland, Elements of Jurisprudence, loth ed., 36, 37; Huxley, Methods and Results Essays, essay entitled Natural Rights and Political Righto; Ritchie, Natural Rights; Salmond, The Law of Nature; 11 Law Quar. Rev. 12r, Bryce, Studies in History and Jurisprudence, II, essay entitled "The Law of Nature;" Pollock, The Expansion of the Common Law, rog, I21; Pollock, The History of the Law of Nature, I Col. L. Rev. 17, 2 Col. L. Rev. 131; Pollock's Maine's Ancient Law, chap. 3; Pollock, The Law of Reason, a Mich. L. Rer. at 168, 169: book reviews, 26 Law Quar. Rev. 173, 167, 168; Willoughby, The Nature of the State, chap. 5i Corwin, The Establishment of Judicial Review, 9 Mich. L. Rev 102, 115, 306. Consider also the discussion in Pound, Common Lat and Legislation, 21 Harv. L. Rev. 383. 